\title{
Bahasa Dan Perkembangan Anak Dalam Pertumbuhan Gramatika
}

Sitti Fauziah Muis

\author{
Institut Agama Islam Negeri Kendari \\ email:uccy_pheat@yahoo.com
}

\begin{abstract}
This study aims to determine the language development in children which is one aspect of the stages of child development and should not escape the attention of educators in general and parents in particular. Therefore, this problem is interesting to study because language acquisition has been intensively studied for a long time.This type of research includes phenomenological qualitative research that is research that examines natural language phenomena. Data collection methods, the researchers adjusted to the conditions in the field, namely a free listening technique involved in proficiency and recorded techniques. This noted technique is intended to observe linguistic phenomena that occur. The results of this study indicate that children's language proficiency is governed by innate maturation factors, children develop language at the same stage no matter where they grow. For example, they all move forward from the chatter stage to the stage where they start saying words. Then they enter a stage in which they put two words together in one sentence (such as: "He Goes") and then follow a period where they increasingly master the structure of sentences that add to the complex.
\end{abstract}

\section{Keywords: Language, Child Development, Grammatical Growth}

\begin{abstract}
Abstrak
Penelitian ini bertujuan untuk mengetahui Perkembangan bahasa pada anak yang merupakan salah satu aspek dari tahapan perkembangan anak serta seharusnya tidak luput juga dari perhatian para pendidik pada umumnya dan orang tua pada khususnya. Oleh sebab itu, masalah ini merupakan hal menarik untuk diteliti sebab pemerolehan bahasa telah ditelaah secara intensif sejak lama. Jenis penelitian ini termasuk penelitian kualitatif fenomenologi yaitu penelitian yang
\end{abstract}


meneliti fenomena kebahasaan yang bersifat natural. Metode pengumpulan data, peneliti sesuaikan dengan kondisi dilapangan yaitu teknik simak bebas libat cakap dan teknik catat. Teknik simak bebas libat cakap dapat dilakukan dengan menyimak penggunaan bahasa tanpa ikut berpartisipasi dalam proses pembicaraan dan teknik catat dilakukan dengan teknik menjaring data dengan mencatat hasil penyimakan pada suatu data tertentu. Teknik catat ini ditujukan untuk mengamati fenomena-fenomena kebahasaan yang terjadi. Adapun sumber data dalam penelitian ini adalah anak-anak peserta didik di PAUD Asy-Syafi'iyah T/A 2018/2019 kota Kendari.Hasil penelitian ini menunjukkan kemahiran berbahasa anak diatur oleh faktor-faktor pendewasaan bawaan, anak-anak mengembangkan bahasa di tahapan yang sama tak peduli dimana pun mereka tumbuh. Sebagai contoh mereka semua bergerak maju dari tahap celoteh menuju tahapan dimana mereka mulai mengucapkan kata-kata. Kemudian mereka memasuki sebuah tahapan yang didalamnya mereka meletakkan dua kata secara bersamaan dalam satu kalimat (seperti: "Dia Pergi") dan kemudian mengikuti sebuah periode dimana mereka semakin menguasai struktur kalimat yang tambah komlpleks.

\section{Kata Kunci: Bahasa, Perkembangan Anak, Pertumbuhan Gramatika}

\section{A. Pendahuluan}

Manusia berinteraksi satu dengan yang lain melalui komunikasi dalam bentuk bahasa. Komunikasi tersebut terjadi baik secara verbal maupun non verbal yaitu dengan tulisan, bacaan dan tanda atau symbol. Manusia berkomunikasi lewat bahasa memerlukan proses yang berkembang dalam tahap-tahap usianya. Bagaimana manusia bisa menggunakan bahasa, sebagai cara berkomunikasi selalu menjadi pertanyaan yang menarik untuk dibahas sehingga memunculkan banyak teori tentang pemerolehan bahasa.

Bahasa adalah simbolisasi dari sesuatu idea atau suatu pemikiran yang ingin dikomunikasikan oleh pengirim pesan dan diterima oleh penerima pesan melalui kode-kode tertentu baik secara verbal maupun 
nonverbal. Bahasa digunakan anak dalam berkomunikasi dan beradaptasi dengan lingkungannya yang dilakukan untuk bertukar gagasan, pikiran dan emosi. Bahasa bisa diekspresikan melalui bicara yang mengacu pada simbol verbal.

Selain itu, bahasa dapat juga diekspresikan melalui tulisan, tanda gestural, dan musik. Bahasa juga dapat mencakup aspek komunikasi nonverbal seperti gestikulasi, gestural atau pantomim. Gestikulasi adalah ekspresi gerakan tangan dan lengan untuk menekankan makna wicara. Pantomim adalah sebuah cara komunikasi yang mengubah komunikasi verbal dengan aksi yang mencakup beberapa gestural (ekspresi gerakan yang menggunakan setiap bagian tubuh) dengan makna yang berbeda beda.

Perkembangan bahasa atau komunikasi pada anak merupakan salah satu aspek dari tahapan perkembangan anak yang seharusnya tidak luput juga dari perhatian para pendidik pada umumnya dan orang tua pada khususnya. Pemerolehan bahasa oleh anak-anak merupakan prestasi manusia yang paling hebat dan menakjubkan. Oleh sebab itulah masalah ini mendapat perhatian besar. Pemerolehan bahasa telah ditelaah secara intensif sejak lama. Pada saat itu kita telah mempelajari banyak hal mengenai bagaimana anak-anak berbicara, mengerti, dan menggunakan bahasa, tetapi sangat sedikit hal yang kita ketahui mengenai proses aktual perkembangan bahasa.

Kemampuan anak menguasai bahasa merupakan keberhasilan yang mengagumkan (Montessori, 1949:515). Bukan pembelajaran kata-kata yang mengesankan pendidik melainkan ketepatan mereka menggunakan gramatika atau sintaksis - sebuah sistem aturan yang menciptakan dan memahami kalimat-kalimat dengan benar. Aturan-aturan gramatika ini begitu kompleks dan tertanam begitu dalam di dalam bahasa-bahasa ucapan sampai-sampai orang dewasa sendiri sulit menyadarinya, tapi entah bagaimana anak sanggup menguasai tanpa mereka sadari kebanyakan dari aturan-aturan tersebut di usia enam tahun. Namun, untuk waktu yang yang cukup lama mereka tidak begitu paham tentang aturan-aturan dan struktur- 
struktur gramatika itu sendiri. Bahkan kemampuan mereka untuk bisa menghitung kata benda dan kata kerja yang digunakan anak-anak sangat terbatas.

\section{B. Pembahasan}

Dalam membahas masalah perkembangan anak dalam pertumbuhan gramatika maka terlebih dahulu perlu untuk mengkaji beberapa teori yaitu Teori Perkembangan Anak yang terdiri dari

\section{a. Teori Chomsky mengenai Perkembangan Anak}

Noam Chomsky lahir pada tahun 1928 di Philadelpia. Dia mempelajari linguistik dari ayahnya (seorang pemikir Yahudi yang disegani) dan belajar linguistik, matematika dan filsafat di Universitas Pennsylvania. Sebenarnya dia bosan dengan kuliah-kuliah itu setelah dua tahun mengikutinya dan bersiap-siap untuk keluar kuliah saat tiba-tiba saja bertemu dengan linguis kenamaan waktu itu, Zellig Harris. Chomsky jadi begitu terserap dengan pekerjaan Harris sehingga mendorongnya untuk mulai membuat inovasinya sendiri. Pada masa-masa inilah, Chomsky meraih gelar sarjana muda sampai doktornya dari Pennsylvania. Meskipun begitu, dia lebih banyak menghabiskan tahun-tahun kesarjanaannya di dalam program spesial di Harvard, yang membuatnya bisa mengajar dimana pun yang dia inginkan. Teori baru Chomsky, sebuah kombinasi matematika dan linguistik, begitu berbeda dari apa pun yang pernah dilakukan orang, sehingga beberapa universitas tidak memiliki tempat baginya. Satu-satunya tawaran kerja hanya datang dari Massachussets Institute of Technology (MIT), tempat dia mengajar sejak tahun 1955 sampai pensiun (Chomsky, 1977:80).

Sebelum Chomsky dikenal, kebanyakan orang percaya kepada temuan teori belajar bahasa Brown yang disebut "Gudang Penyimpanan". Anak-anak mengimitasi orang lain dan memperoleh sejumlah besar kalimat yang mereka simpan di kepala mereka. Kemudian mereka mencapai 
penyusunan kalimat yang tepat saat kejadian-kejadian tertentu muncul (Brown dan Herrnstein, 1975:444).

Chomsky sebaliknya, membuktikan kalau pandangan ini tidak tepat. Manusia tidak hanya belajar sejumlah kalimat, karena secara rutin kita selalu menciptakan kalimat-kalimat baru. Seperti ketika menulis buku, saya menggunakan kata-kata yang sama berulang-ulang, namun saya menciptakan sebuah kalimat baru setiap kali menurut kabutuhan. Kita juga melakukan hal yang sama setiap kali berbicara atau menulis apa pun. Dalam hal ini terjadi karena kita memiliki aturan-aturan internal yang memampukan kita membuat kalimat yang sesuai aturan gramatika untuk menyatakan makna-makna yang kita maksudkan. Jika kita hanya dapat menggunakan kalimat-kalimat yang sudah pernah didengar dan diingat, bahasa kita mestinya sangat terbatas. Karena kita memiliki sistem aturan tertentu yaitu sebuah gramatika maka kita bisa menemukan dan memahami kalimat-kalimat yang tidak pernah didengar sebelumnya (Chomsky, 1959:56).

\section{b. Teori Montessori Tentang Periode Kepekaan}

Komponen utama teori Montessori adalah konsep periode-periode kepekaan. Periode-periode kepekaan (sensitive periods) mirip dengan periode-periode kritis; secara genetis mereka sudah diprogram untuk memblokir waktu sehingga pada waktu tertentu, anak begitu ingin dan mampu menguasai tugas-tugas tertentu. Sebagai contoh, terdapat periodeperiode kepekaan untuk menguasai bahasa dan untuk memulai penggunaan tangan. Selama periode-periode ini, anak bekerja dengan semua daya upayanya untuk menguasai kemampuan-kemampuan tersebut sampai sempurna. Dan "Jika anak dicegah dari menikmati pengalaman-pengalaman ini pada waktu tertentu yang sudah direncanakan alam agar berbuat demikian, maka kepekaan khusus yang menariknya kepada hal-hal tersebut akan hilang, mengakibatkan gangguan pada perkembangannya...”(Montessori, 1949:95). 
Untuk mempelajari sebuah bahasa, anak-anak harus belajar bukan hanya kata-kata atau maknanya, namun juga gramatikanya. Sebuah sistem aturan yang memberitahukan mereka tempat bermacam-macam bagian ujaran. Jika, contohnya, kita mengatakan, "The tumbler is on the table" (Gelas terletak di atas meja) maka arti yang kita berikan kepada kata-kata tersebut berasal dari sebuah aturan yang membuat kita berkata demikian. Jika kita terbalik-balik mengatakannya, contohnya "On tumbler the is table the" (Di atas gelas terletak meja), maka artinya sulit sekali kita pahami (Montessori, 1949:25). Aturan-aturan yang melandasi gramatika begitu sulit dipahami dan abstrak, sampai-sampai para cendekia bahasa masih berusaha memahaminya dengan cara yang formal. Namun anak-anak menguasai hal ini tanpa banyak memikirkannya. Jika seorang anak diajari dua bahasa, mereka akan sanggup menguasai keduanya (1949: 111).

Karena kemampuan anak untuk memahami bahasa begitu besar, Montessori menyimpulkan kalau anak harus dilengkapi dengan jenis khusus penerimaan atau mekanisme bahasa. Mekanisme ini sangat berbeda dari apa pun yang ada di dalam kehidupan mental anak-anak yang lebih tua atau orang dewasa. Sementara kita harus belajar bahasa kedua dengan usaha yang sangat keras, secara sadar berupaya mengingat-ingat aturan-aturan kalimat, kata depan, kata sifat, dan seterusnya, anak-anak menyerap bahasa secara tidak disadari.

Menurut Montessori, kemahiran berbahasa anak-anak banyak mirip dengan konsep pencetakan (imprinting). Pada masa kritis tertentu, dari bulan-bulan pertama kehidupan sampai dua setengah tahun, anak-anak secara bawaan bersiap-siap menyerap suara, kata-kata dan gramatika dari lingkungan. "Anak-anak menyerap imresi-impresi ini bukan dengan pikirannya, melainkan oleh hidupnya sendiri. (1949:24). Suara menciptakan impresi-impresi tentang intensitas dan emosi yang menakjubkan. Mereka harus diletakkan di dalam pergerakkan jejaringan yang tidak kelihatan di dalam tubuh si anak. Jaringan yang mulai bergetar dalam upayanya untuk mereproduksi suara-suara tersebut. Kita orang dewasa sulit 
Membayangkan pengalaman seperti apa ini, kecuali mungkin dengan mengingat perasaan yang kita peroleh saat kita tergerak sangat mendalam oleh sebuah simfoni dan kemudian membayangkan perasaan yang beberapa kali lebih kuat pada anak-anak. Kepekaan khusus pada bahasa mulai bekerja selama tahun pertama atau lebih dan kemudian menghilang.

Kemahiran bahasa diatur oleh faktor-faktor pendewasaan bawaan, anak-anak mengembangkan bahasa di tahapan yang sama tak peduli dimana pun mereka tumbuh. Sebagai contoh mereka semua bergerak maju dari tahap celoteh menuju tahapan dimana mereka mulai mengucapkan katakata. Kemudian mereka memasuki sebuah tahapan yang didalamnya mereka meletakkan dua kata secara bersamaan dalam satu kalimat (seperti: "Dia Pergi") dan kemudian mengikuti sebuah periode dimana mereka semakin menguasai struktur kalimat yang tambah komlpleks.

Tahapan-tahapan ini tidak berlangsung secara gradual atau berurutan. Karena ada juga beberapa moment ketika anak-anak tidak membuat kemajuan apa pun, dan kemudian keberhasilan baru datang lagi secara hebat. Sebagai contoh, anak-anak tiba-tiba melontarkan sejumlah kata-kata baru atau tiba-tiba menguasai seperangkat aturan untuk membentuk bagian-bagian ujaran, seperti kata awal dan akhiran, dalam sebuah ledakan yang mendadak (1949:114).

Antar usia tiga sampai enam tahun, anak-anak tidak lagi menyerap kata-kata dan gramatika secara tidak sadar, tapi mereka masih berada di dalam periode sensitif umum akan bahasa. Selama waktu ini, mereka lebih sadar dengan mempelajari bentuk-bentuk gramatika baru dan sangat gembira saat melakukannya. Ketika anak menginjak usia lima atau enam tahun, dan siap untuk menjalani sekolah tradisional, maka pada saat itu anak sudah mulai untuk berbicara dan semuanya terjadi tanpa keterlibatan seorang guru. 


\section{Hipotesis Bawaan (Innate Hypothesis)}

Chomsky mengatakan kalau pencapaian linguistik anak-anak pada umumnya terlalu besar untuk bisa dijelaskan jika kita beranggapan hal itu diajarkan oleh lingkungan. Anak-anak mendengar hanya badan ujaran yang terbatas, kebanyakan dibentuk dengan buruk, namun mereka bisa mengembangkan dengan cepat dan seragam sistem aturan yang rumit untuk menciptakan jumlah kalimat yang tidak terhitung jumlahnya. Pengetahuan mereka berkembang jauh melebihi pengalaman mereka. Kita hanya bisa menyimpulkan, bahwa anak-anak tidak membangun gramatika dari buktibukti yang mereka dengar, melainkan dari rancangan batin (sebuah program genetik), (Chomsky, 1980:232-234).

Chomsky suka membandingkan perkembangan gramatika dengan pertumbuhan organ-organ fisik, seperti jantung, atau alat-alat penglihatan embrionik. Disini sangat jelas kalau struktur-struktur yang muncul terlalu rumit untuk bisa dijelaskan hanya lewat masukan lingkungan (seperti oksigen dan nutrisi). Lingkungan memang vital, namun dia hanya mendukung atau mengaktifkan pola-pola yang secara intrinsik sudah ditentukan. Dengan cara yang sama sederhananya, lingkungan linguistik utamanya memacu pengkonstruksian sistem-sistem gramatika yang polanya sudah ditentukan oleh cetak-biru genetik manusia (1980:33).

Namun ada pertanyaan yang kemudian muncul, bahwa bahasa tidak seperti organ-organ fisik, sangat beragam dari budaya ke budaya dan bahasa yang dipelajari anak bergantung kepada budaya tempatnya dibesarkan. Jadi bagaimana cara kerja proses pembelajaran bahasa bawaan seperti ini?

Ketika anak menguasai sebuah gramatika, mereka dituntun oleh pengetahuan bawaan mengenai bawaan mengenai gramatika universal. Secara otomatis mereka tahu bentuk umum bahasa yang harus diambil. Namun, gramatika universal (UG, universal grammar) ini memiliki celah di dalamnya, membiarkan parameter tertentu terbuka. Sebagai contoh, salah satu prinsip UG adalah semua kalimat mestinya mengandung satu topik, namun beberapa bahasa mengizinkan pembicara untuk secara rutin 
membiarkan topik ini implisit, yaitu ketika pembicara tidak harus menyuarakannya. Dalam bahasa italia kita bisa hanya mengatakan 'pergi' di mana dalam bahasa Inggris orang harus mengatakan 'Dia Pergi' (Hyams, 1986:22). Kalau begitu anak-anak memerlukan informasi dari lingkungan untuk menyiapkan parameter ini, menentukan aturan mana yang sedang diikuti bahasa mereka.

Menurut Chomsky, penyiapan parameter oleh anak ini bukan masalah yang sulit, sama seperti kita menyiapkan pergantian + atau -. Selain itu, jumlah pergantian yang harus disiapkan juga tidak banyak. Karena itu, persyaratan gramatika yang dibutuhkan hanyalah sejumlah kecil masukan dari lingkungan (Chomsky, 1986:146).

Namun yang belum jelas disini adalah jika model penyiapan parameter ini sungguh mendeskripsikan cara anak mempelajari gramatika tertentu. Ketika memadukan kata-kata secara bersama-sama, mestinya mereka mengetahui secara intuitif bahwa kombinasi tertentu bisa dilakukan, sedangkan yang lain tidak. Mengapa demikian? Karena jika kita masih menganggap anak belajar gramatika hanya dari pengalaman saja, maka jika mereka kekurangan pengetahuan seperti ini, anak-anak tidak akan pernah bisa menguasai sistem yang kompleks itu dalam waktu singkat.

Kemampuan anak belajar bahasa merupakan sesuatu yang spesifik bagi spesies (ditemukan hanya pada manusia), dan menjadi kemampuan istimewa di dalam pikiran manusia. Artinya, sebuah kemampuan yang tidak bisa disamakan begitu saja dengan kemampuan belajar sains, musik dan seterusnya. Kemampuan ini sudah memiliki rancangan genetiknya sendiri (1983:37).

\section{Struktur-Permukaan dan Struktur-Dalam}

Saat kita menciptakan, memahami dan mentransformasikan kalimat, secara intuitif kita bekerja di dua tingkatan: mengikuti stuktur permukaan (surface-structure) dan struktur dalam (deep-structure) kalimat-kalimat. Penggunaan Chomsky atas konsep-konsep ini sangat abstrak dan teknis, 
namun kita bisa menangkap ide-idenya lewat beberapa contoh. Perhatikan dua kalimat berikut ini:

$>$ John is eager to please (John ingin sekali menyenangkan).

$>$ John is easy to please (John mudah sekali menyenagkan).

Dipermukaan, dua kalimat ini memiliki struktur yang sama: subjek (John), kata kerja (is), kata sifat (eager/easy), dan kata keterangan (to please). Namun secara intuitif kita tahu kalau makna yang mendasari keduanya sangat berbeda, seperti dinyatakan oleh struktur mereka yang lebih dalam. Pada kalimat pertama, John adalah subjek; Dia adalah orang yang ingin menyenangkan orang lain. Pada kalimat kedua, John adalah objek; orang lain yang membuatnya senang. Kalau begitu, dua kalimat ini memiliki perbedaan struktur yang melandasinya.

Perbedaan antara struktur-permukaan dan struktur-dalam ini sangat penting jika dikaitkan dengan trnasformasi yang hendak kita lakukan. Bandingkan kalimat-kalimat berikut:

$>$ Susan is the apple (Susan seperti buah apel).

> The apple was eaten by Susan (Buah apel dimakan Susan)

> Susan did not eat the apple (Susan tidak makan buah apel)

$>$ What did Susan eat? (Apa yang dimakan Susan?)

$>$ Susan ate the aple, didn't she? (Susan memakan buah apel, bukan?)

Dari kalimat-kalimat ini, kalimat kelima adalah yang paling gamblang. Kalimat ini sederhana, deklaratif dan mengikuti urutan S-P-O, subjek-kata kerja-objek. Didalam bahasa Inggris, bentuk dikenal paling dekat (namun tidak identik) dengan struktur-dalam yang abstrak. Kalimat kelima, adalah inti dasar yang diatasnya kita melakukan operasi-operasi bahasa tertentu untuk menciptakan kalimat lain. Kita bisa memunculkan kalimat-kalimat lain, dengan mengikuti seperangkat operasi bahasa yang jelas untuk menciptakan bentuk lain (Chomsky, 1965:138-141).

\section{Pertumbuhan Gramatika Anak}


Secara umum perkembangan bersifat 'instan', bahwa anak-anak secara instan mengembangkan struktur-struktur gramatika orang dewasa. Namun, ini hanya asumsi awal saja, Chomsky juga menyadari bahwa kemampuan gramatika, seperti sistem biologis apa pun, dapat berkembang jadi matang, bahkan menjalani tahapan-tahapan yang secara kualitatif berbeda (1975:119-123).

\section{Bahasa Awal}

Sejak lahir, bayi tampaknya terserap ke dalam bahasa. Analisis cermat terhadap sebuah rekaman film menunjukkan kalau bayi membuat gerakan-gerakan tubuh yang sangat halus sebagai respons kepada ucapan, dan gerakan mereka jadi beragam sesuai ikatan suara dan kata-kata dari ucapan tersebut. Gerakan-gerakan demikian tidak dibuat untuk merespons suara-suara lain, seperti langkah kaki (Cordon dan Sander, 1974)

Kira-kira pada usia satu bulan, bayi mulai mendeguk dan menjekut, dan pada usia enam bulan mereka biasanya mulai meraba, membuat suarasuara getaran bibir dan lidah seperti 'ba ba ba' atau 'da da da'. Vokalisasi awal bayi ini tampaknya sama diseluruh dunia (Sachs, 1976:148).

\section{Pengucapan Satu - Kata}

Pada usia sekitar satu tahun, bayi mulai memproduksi kata-kata tunggal. Beberapa peneliti percaya kalau mereka berusaha menggunakan kata-kata tunggal untuk mengekspresikan seluruh kalimat. Contohnya, 'kue' berarti 'Aku ingin kue' atau 'Disana ada kue', bergantung pada konteksnya. Namun, sangat berbahaya kalau kita terlalu banyak terserap ke dalam ucapan bayi (Sachs, 1976).

\section{Pengucapan Dua - Kata}

Sekitar mulai satu setengah tahun, anak-anak meletakkan dua kata bersama-sama, dan bahasa mereka menunjukkan struktur tertentu. Namun, para peneliti sendiri tidak sepakat dengan ciri utama struktur ini. Pada tabel di bawah ini mendata sejumlah ucapan dua - kata ini, seperti yang dikaji beberapa ahli psikolinguistik. 
Tabel 1: Beberapa Ucapan Dua - Kalimat yang Khas

\begin{tabular}{|l|l|l|}
\hline No. & Jenis & Contoh \\
\hline $\mathbf{1 .}$ & Penamaan & Anjing itu \\
$\mathbf{2 .}$ & Pengulangan & Melompat lagi \\
$\mathbf{3 .}$ & Penegasian & Bola hilang, tidak basah \\
$\mathbf{4 .}$ & Kepemilikan & Mobil saya \\
$\mathbf{5 .}$ & Atribut & Anak besar \\
$\mathbf{6 .}$ & Agen-aksi & Joni memukul \\
$\mathbf{7 .}$ & Aksi-objek & Memukul bola \\
$\mathbf{8 .}$ & Agen-objek & Ibu roti (artinya, 'Ibu sedang \\
& & memotong roti') \\
\hline
\end{tabular}

Sumber: Diadaptasi dari Brown dan Herrnstein (1975:478) dan Slobin (1979:85-87)

Perhatikan bagaimana di dalam ucapan 6 dan 8 anak-anak memisahkan agen, aksi dan objek. Beberapa orang menganggap kalau anak memiliki pengetahuan dasar tentang hubungan subjek - kata kerja - objek. Namun begitu hal ini tidak bisa di pastikan juga. Ketika anak-anak menggunakan agen-agen, mereka tidak perlu menggunakan subjek. Agen merupakan kategori semantik (makna-kata) yang terbatas, mengacu hanya kepada sesuatu yang melakukan aksi. Subjek merupakan kategori sintaksis yang lebih luas, mengacu kepada bagian kalimat yang melakukan aksi, atau bisa juga tidak (contohnya, tidak ada aksi di dalam kalimat 'Dia bertubuh tinggi'). Karena itu, para peneliti yang menyimpulkan sintaksis orang dewasa dari ucapan anak bisa dikatakan terlalu terserap ke dalamnya (Gardner, 1982:168-170).

\section{Pengembangan Gramatika}

Antara usia dua sampai tiga tahun, anak biasanya meletakkan tiga atau lebih kata secara bersamaan, mengatakan hal-hal seperti "I making coffee". Yang biasanya mengatakan hal-hal seperti "Eve is girl" (Brown, 1973:314), sekarang mulai menggunakan subjek dan predikat yang melampaui fungsinya sekedar sebagai agen dan tindakan saja (Eve isn't 
doing anything). Ucapan anak-anak biasanya mengikuti urutan S-P-O, sesuatu yang integral dengan struktur dalam bahasa Inggris pada umumnya (Brown, dkk, 1969:42).

Namun, setelah mulai meletakkan tiga atau lebih kata secara bersamaan, anak mulai menunjukkan bahwa mereka memahami ketergantungan, pada struktur bahwa frase-frase kata benda merupakan satu unit yang menyeluruh. Mereka menyatakan hal-hal seperti ini, lewat penjedaan contohnya, seperti seorang anak berkata "Put....the red hat...on", bukannya "Put the ....red hat...on". Anak tahu kalau frase "the red hat" berfungsi sebagai satu unit yang tidak boleh dipotong (Brown dan Bellugi, 1964:150). Berikutnya, ketika anak mulai mengubah kalimat, mereka akan menghargai integritas unit-unit ini.

Selama fase ini, anak juga mulai suka menggunakan akhiran kata, dan ketika melakukannya, mereka terlalu teratur (overregularize), contohnya seperti mengatakan "I runned", It doed" dan She doed it". Proses yang sama juga terjadi pada kata-kata jamak, anak biasa mengatakan hal-hal seperti 'foots', 'mans'dan 'mouses' (Ervin, 1964; Slobin, 1972).

Yang menarik adalah anak tidak mulai dari keteraturan yang berlebihan seperti ini, melainkan bentuk yang tidak teratur yang benar. Sebagai contoh, seorang anak berkata 'went' sebelum berkata 'goed'. Namun, setelah satu bulan atau lebih, mereka mulai melebih-lebihkan akhiran kata dan terus melakukannya sampai tahun-tahun di sekolah dasar.

Apa yang mereka lakukan, sebagian besar ahli psikolinguistik percaya, adalah perumusan aturan-aturan. Mereka menemukan kalau aturan membentuk past tenseadalah dengan menambahkan bunyi 'ed' yang kemudian diterapkan di semua kata, berasumsi kalau bahasa lebih konsisten dari yang sebenarnya. Dengan cara yang sama, mereka menyimpulkan bahwa aturan untuk menciptakan kata jamak adalah dengan menambahkan bunyi '-s-', yang kemudian mereka terapkan secara luas.

Seperti sudah disebutkan sebelumnya, para ahli psikolinguistik mencari-cari sintaksis orang dewasa di dalam ucapan anak-anak. Para 
developmentalis di dalam tradisi Rousseauis, sebaliknya lebih tertarik kepada ujaran anak yang mungkin memang berbeda secara kualitatif ketimbang ujaran orang dewasa. Keteraturan yang berlebihan ini sungguh memberikan sentuhan yang unik kepada ujaran anak, meski yang dilakukan anak sesungguhnya adalah mengatur secara berlebihan aturan ujaran orang dewasa. Kalau ini yang terjadi, maka kita ingin tahu apakah anak juga ikut merumuskan aturan mereka sendiri.

Kemungkinan ini mengejutkan Klima dan Bellugi (1966) waktu menguji kalimat-kalimat negatif anak-anak. Awalnya anak bertindak seolaholah aturan mereka adalah: Letakkan kata negatif di depan seluruh kalimat (atau di belakang). Contohnya, mereka berkata, "No play that", "No want stand head", atau "Car go no". Setelah itu anak-anak tampaknya mulai membentuk sebuah aturan baru: meletakkan kata negatif setelah frase kata benda pertama, sebelum kata-katab lainnya. Maka berkata seperti, "He no bite you", dan "I no want envelope".

Dengan kecepatan yang berbeda, kalau begitu, anak menstrukturkan kata negatif dengan caranya sendiri. Beberapa peneliti menyatakan bahwa kalimat-kalimat awal anak ini berdekatan dengan struktur-dalam kalimat orang dewasa, meskipun struktur-dalam murni teoretis sehingga tidak akan pernah bisa langsung dipahami anak. Dengan kata lain, di dalam kasus apa pun, kata negatif pada anak-anak benar-benar memiliki kualitas istimewanya sendiri. Seperti dikatakan Klima dan Bellugi (1996:191), "Tampaknya bagi kita kalau bahasa anak-anak memiliki sistematikanya sendiri, dan bahwa kalimat anak-anak bukan hanya salinan sempurna kalimat orang dewasa".

\section{Perubahan-Perubahan}

Antara usia tiga sampai enam tahun, gramatika anak-anak berubah dengan cepat menjadi cukup kompleks. Umumnya mereka membuat banyak perubahan disini. Bellugi-Klima (1968) mempelajari bagaimana anak membentuk kata tanya 'Di mana', dan 'Kenapa' dari pengubahan strukturdalam kalimat itu sendiri. Sebagai contoh, "Where can I put it?" (Dimana 
aku bisa meletakkan ini?) pada essensinya merupakan transformasi dari kalimat "I can put it where" (tidak bisa diterjemahkan).

Anak-anak tidak dapat menguasai operasi-operasi pengubahan kalimat sekaligus, karena itu mereka melewati tahapan-tahapan seperti yang dilakukan pada kalimat-kalimat negatif. Contohnya, mereka melalui sebuah periode di mana mereka mengatakan hal-hal seperti "Where I can put it?" dan "What he wants?" Mereka memindahkan kata tanya 'Where' dan 'What' ke depan kalimat, tapi membiarkan sisa kalimat tidak diubah (tetap mempertahankan aturan S-P-O). Bahkan ketika diminta meniru sekalipun, umumnya mereka tetap menempelkan kata-kata itu kepada cara mereka berbicara, contohnya:

Orang Deawasa : : "Adam, tirukan perkataan saya: Where can I put them?"

Adam : “Where I can put them?”. (Slobin, 1979:96).

\section{Mendekati Gramatika Orang Dewasa}

Meskipun anak menguasai banyak aspek gramatika di usia 5 atau 6 tahun, namun sejumlah pengubahan kalimat yang kompleks masih tidak mampu mereka lakukan. Sebagai contoh, mereka tampaknya kesulitan dengan kalimat pasif sampai usia tujuh tahun atau lebih (Turner dan Rommetveit, 1967). Namun begitu, usia 5 sampai 10 tetap saja penting untuk menentukan kemampuan gramatika anak yang paling halus dan kompleks. (C.Chomsky, 1969).

\section{Universalia}

Banyak ahli psikolinguistik memercayai keberadaan universalia di dalam proses perkembangan anak. Sejauh ini bukti terkuat hanya ditemukan dari fase-fase awal saja. Dimana- mana anak melangkah maju dengan menggetarkan lidah dan bibir mereka untuk menjadi ucapan satu atau dua kata, dan kelihatannya hal seperti ini hampir sama di seluruh dunia (Brown dan Herrnstein, 1975: 477-479). 
Pencarian sifat-sifat universal sintaksis setelah fase dua-kata menjadi sangat sulit, dan penyelidikan seperti ini baru saja dimulai. Beberapa bukti menunjukkan bahwa di mana-mana anak awalnya selalu mengucapkan kalimat negatif dengan cara yang sama, bahkan terlalu-teratur di beberapa bagian ucapanmya (Cairns, 1976:205). Namun, ketika mulai menguasai pengubahan-pengubahan kalimat, jelas mereka menggunakan aturan yang berbeda dari bahasa satu ke bahasa lain. Walaupun begitu, aturan-aturan ini bisa saja mengandung sejumlah keterbatasan yang bersifat universal, seperti ketergantungan pada struktur diatas, sehinggan membatasi aturan kalimat yang akan mereka bentuk nantinya.

\section{Pengondisian Operan}

Bayi berceloteh dengan bibir dan lidahnya sampai secara kebetulan , memukul bunyi yang mirip sebuah kata, dan kemudian diperkuat. Contohnya, mereka berkata 'pa pa' ketika melihat ayah datang, dan orang tuanya tersenyum sebagai tanda celotehnya benar. Lalu secara bertahap, orang tua terus memberikan persetujuan terhadap semakin akurat dan kompleksnya ucapan mereka.

Akan tetapi, Skinner sendiri dan pengikutnya (Lovaas, 1977) menganggap pengamatan bagi pembentukan setiap ucapan seperti ini sebagai proses yang terlalu lambat untuk bisa memahami perkembangan bahasa anak yang sangat cepat. Karena itu, anak sebaiknya diajari langsung perilaku linguistik yang spesifik, agar mereka dapat segera menggeneralisasikan pembelajaran itu bagi situasi-situasi baru. Contohnya, seorang anak yang diajar menjamakkan sebuah kata, secara otomatis akan menjamakkan kata-kata baru jika tidak dilatih lagi. Dan karena anak sanggup menggeneralisasikan seperti ini, maka mereka pun siap untuk memproduksi ujaran-ujaran yang baru sama sekali.

Prinsip penggeneralisasian tampaknya bisa menjelaskan fenomena keteraturan yang berlebihan (seperti 'mans'). Kita bisa melihatnya dari pembuktian prinsip-prinsip operan di dalam riset laboratorium yang umumnya menghadapi anak-anak terbelakang atau terganggu sehingga 
lambat perkembangan bicaranya. Anak-anak ini hanya diajari kata-kata plural, kata depan dan unsur-unsur gramatis lain yang agak sederhana, namun anehnya mereka dapat menerapkan pelajaran itu dengan cepat sekali pada situasi-situasi baru (Lovaas, 1977:110-116). Namun sayangnya, teknik-teknik operan belum bisa meneliti pengubahan gramatika yang lebih kompleks, apalagi awalnya anak sudah menggunakan bentuk tak-teratur secara benar (seperti 'men') bahkan sudah memperoleh penguatan darinya.

Jawaban masalah ini mungkin bisa diperoleh dari penelitian Brown dan Hanlon (1970). Mereka menemukan kalau anak normal menghadapi kesulitan besar mempelajari bahasa karena pengondisian yang dilakukan oleh orang tua mereka sendiri. Bagaimanapun, orang tua adalah guru bahasa yang buruk. Para peneliti ini lalu menemukan kalau orang tua hanya mengoreksi beberapa ucapan tidak-gramatis yang menyolok saja. Jadi mereka lebih berkonsentrasi pada benar tidaknya uacapan anak. Contohnya, ketika seorang gadis kecil, Sarah berkata,"Her curl my hair", maka ibunya berkata, "Ya, benar," karena memang itulah yang sedang dilakukannya, mengeriting rambut Sarah. Ibu mengabaikan kekeliruan kosa kata dan gramatika Sarah. Namun sebaliknya, waktu Sarah berkata, "There's the animal farmhouse", sebuah kalimat yang cacat secara gramatis, ibu langsung mengoreksi karena burung-burung yang dilihat Sarah itu bukan berada di rumah pertanian, melainkan di dalam mercusuar (1970:202). Kalau begitu, Sarah belajar bahwa gramatika adalah konsekuensi dari efek persetujuan atau ketidaksetujuan orang tuanya.

Tapi mungkin bukan persetujuan orang tua, melainkan bentuk umpan balik lain yang melandasi penguatan efektif ini. Mungkin anak mulai belajar menggunakan gramatika yang semakin tepat karena orang tua tidak memahami dan merespons secara akurat ucapan mereka. Namun demikian, Brown dan Hanlon juga gagal menemukan apakah ucapan-ucapan yang baik bentuknya selalu disambut dengan pemahaman yang baik dari orang tua daripada ucapan-ucapan yang tidak baik bentuknya. Data Brown dan Hanlon didasarkan hanya kepada tiga anak, namun ketiganya sudah belajar 
gramatika yang benar meskipun sedikit saja memperoleh penguatan langsung dari orang tua mereka.

Disisi lain, sejumlah riset teori belajar paling menakjubkan telah difokuskan untuk bisa mengajarkan bahasa tanda kepada kera. Harapannya, mereka bisa membuktikan efektivitas prosedur mereka dan menyanggah pernyataan Chomsky bahwa pembelajaran bahasa merupakan kemampuanbawaan yang hanya dimiliki manusia. Untuk melakukan riset ini, beberapa teori belajar menggunakan teknik operan, semetara yang lain mencampurkannya dengan metode lain. Hasilnya, sebagian besar dan cukup mengejutkan, tidak ada yang bisa mengajarkan bahasa kepada kera dengan fleksibilitas dan kreativitas seperti dimiliki anak manusia di fase dua-kata (Gleitman, 1986:331-332). Bagi Chomsky sendiri, hasil itu juga mengejutkannya. Penemuan bahwa kera bisa belajar bahasa, menurutnya "mirip dengan penemuan, disuatu pulau yang belum pernah dijelajahi, spesies burung yang tidak pernah mengira bisa terbang sampai kemudian diperintah demikian lewat campur tangan manusia. (1980:239)

Dengan kata lain, teori operan berpotensi untuk memberikan cukup banyak bukti yang bisa melemahkan teori Chomsky. Namun sayangnya, hasil akhir penelitian lewat teori operan semakin mengakui keberadaan batasan-bawah dalam memengaruhi kemampuan atau ketidakmampuan spesies untuk belajar. Meskipun begitu, teori operan dan riset-riset sejenis masih terus berkembang dan semakin menantang pandangan Chomsky dengan cara-cara yang lebih menarik.

\section{Bandura dan Pemodelan}

Bandura menekankan pengaruh pemodelan. Dia mengakui kalau pemodelan tidak selalu bekerja lewat proses imitasi yang ketat, karena anakanak juga menghasilkan ucapan-ucapan baru yang mereka sendiri tidak pernah mendengarnya. Contohnya, keteraturan yang berlebihan pada ucapan anak (seperti 'mans') tidak mungkin imitasi yang benar karena orang dewasa tidak bicara demikian. Namun begitu, Bandura yakin kalau pemodelan masih bekerja, lewat salah satu prosesnya yang disebut 
'pemodelan abstrak'. Anak meniru aturan-aturan yang mereka dengar (seperti menambahkan bunyi 's' untuk menandakan kejamakan), yang kemudian mereka tiru terlalu baik (Bandura, 1977:175).

Beberapa riset laboratorium mendukung pendapat Bandura ini. Whitehurst dkk (1974) contohnya, menunjukkan bahwa model yang cermat menggunakan kalimat pasif akan menghasilkan kepasifan pada kalimat anak. Anak tidak hanya menyalin kata-kata model secara persis, tapi juga mengambil struktur umum kalimat pasif dan menciptakan kalimat-kalimat baru dari jenis ini.

Chomsky tidak langsung mengomentari pernyataan Bandura ini, namun kita bisa membayangkan kalau responsnya akan seperti berikut. Di dunia nyata, model memang bisa mencontohkan sejumlah aturan kalimat yang cukup jelas sehingga anak menggunakannya berdasarkan model tersebut. Seiring berjalannya waktu, model juga memberi anak tubuh ucapan yang terbatas dan sering kali ambigu. Sebagai contoh, mereka sering membuat kalimat yang mengandung aturan tergantung pada struktur maupun tidak tergantung pada struktur, namun sangat jarang kalimat yang mendorong anak memilih salah satu aturan ini. Belum lagi, banyak ujaran orang dewasa yang rusak, penuh kesalahan, selip lidah, mengawali kalimat secara keliru dan sebagainya. Dengan kata lain, meskipun anak menyerap aturan pembuatan kalimat dari ujaran yang didengar selama ini, namun akhirnya mereka bisa memproduksi kalimat yang benar semata-mata hanya karena dituntun oleh pemahaman bawaan mengenai aturan itu sendiri.

Meskipun percakapan di antara orang dewasa bisa penuh dengan kesalahan, namun cara orang dewasa berbicara kepada anak adalah lewat gramatika yang pendek, sederhana dan jelas. Ujaran seperti ini sering disebut 'jawaban-ibu' (motherese), bisa dilihat dari ilustrasi yang direkam Brown dan Bellugi (1964:135):

Adam : See truck, Mommy. See truck.

Ibu : Apakah kamu melihat truk itu lewat?

Adam : No, I see truck. 
Ibu : Tidak, kamu tidak melihatnya lewat? Nah itu ada satu lagi Adam : There go one.

Ibu : : Ya, itu ada satu truck lagi

Adam : See a truck. See truck, Mommy. See truck. Truck. Put truck, Mommy.

Ibu : Membawa truk ke mana?

Adam : Put truck window.

Ibu : Ibu kira truk itu terlalu besar untuk dibawa masuk lewat jendela.

Kecuali untuk kalimat yang terakhir ini, ucapan pendek-pendek saja, dan tampaknya gramatikanya sudah sempurna. Cukup mudah bagi Adam untuk meniru kalimat-kalimat ini, yang dilakukannya dari satu titik pandang, katakanlah, "There go one”. Ibu menanggapinya dengan 'peniruan yang dikembangkan' (expanded imitation), "Yes, there goes one". Dengan kata lain, ibu meniru kalimat Adam dan mengembangkannya sedikit. Bisa jadi peniruan yang dikembangkan semacam ini secara bertahap bisa membawa anak menuju bentuk gramatika baru.

Penemuan tentang jawaban-ibu ini mungkin bisa menunjukkan kalau pemodelan bisa jauh lebih efektif ketimbang yang sudah dilakukan Chomsky. Jika model ucapan orang dewasa dikatakan dalam bentuk sederhana, jelas, dan benar maka anak bisa belajar darinya.

Namun begitu, kita belum bisa menarik kesimpulan apa pun tentang pengaruh pemodelan ini. Untuk satu sisi, kita belum tahu seberapa penting jawaban-ibu bagi anaknya. Bukti terbaru memperlihatkan kalau jawaban-ibu memang dapat mempercepat sedikit perolehan bahasa oleh anak, meski ada juga anak yang belajar bahasa tanpa melewati jawaban-ibu ini. Orang dewasa dibeberapa budaya, suku Kulali di Papua Nugini contohnya, tidak mempercayai penggunaan 'ujaran-yang-disederhanakan' (simplified speech) semacam itu, kendati anak mereka masih belajar bahasa secara kasar seperti yang dilakukan anak-anak di Amerika Serikat (Sroufe dan Cooper, 1988:279-282). 
Meskipun ujaran yang disederhanakan dapat mempercepat sedikit pembelajaran bahasa, namun hal ini masih belum bisa menginformasikan titik-titik kuncinya. Bahkan mungkin ujaran yang disederhanakan tidak menyediakan informasi yang dibutuhkan anak bahwa semua aturan mestinya tergantung pada struktur usia mereka untuk mengetahui semua ini.

Akhirnya, ada bukti lain yang mengingatkan kita agar tidak menekankan terlalu banyak pengaruh pemodelan. Anak terkadang menciptakan struktur-struktur gramatika yang tidak begitu mirip dengan yang dimiliki orang dewasa. Contohnya, bagaimana anak awalnya meletakkan kata 'no' di awal atau akhir kalimat, sesuatu yang tidak pernah dicontohkan orang dewasa. Adam melakukannya pada contoh di atas dengan berkata, "No, I see truck". Jadi, anak-anak kelihatannya tidak begitu saja meniru aturan orang dewasa melainkan membentuk aturan mereka sendiri. Tapi ironisnya, Chomsky dan para pengikutnya (seperti Lightfoot,1982:184) telah meminimalkan pentingnya struktur ini, menganggap hanya muncul di awal perkembangan gramatika orang dewasa.

Kesimpulannya, kalau begitu penemuan ujaran yang disederhanakan menyiratkan kalau pemodelan bisa lebih membantu anak belajar bahasa daripada metode yang ditawarkan Chomsky. Namun demikian, kita tidak boleh mengiyakan begitu saja kesimpulan bahwa ujaran anak merupakan hasil dari pengaruh-pengaruh pemodelan. Karena mungkin juga anak memang memproses sebuah pemahaman-bawaan mengenai bentuk-bentuk gramatika umum, dan bahwa mereka kadang kala menstrukturkan bahasa dengan cara yang berbeda dari model-model tersebut.

\section{Implikasi Bagi Pendidikan}

Chomsky menyatakan kalau anak belajar sistem gramatis yang luas dan rumit hampir-hampir dengan cara mereka sendiri. Yang mereka butuhkan hanyalah mendengar bahasa yang diucapkan, kemudian mereka akan menguasainya tanpa program pelatihan apa pun. Ini terjadi pada anak yang hidup di lingkungan kumuh, atau anak kelas menengah di pinggiran kota. Mereka mempelajari bahasa di jalanan, tanpa siapapun memperhatikan 
kemajuan mereka. Bahkan anak-anak imigran di lingkungan bawah berhasil menguasai bukan hanya satu bahasa baru, tapi dua (Chomsky, 1977:.88)

Karena Chomsky percaya anak belajar secara spontan, dia pun tidak mengusulkan metode instruksional yang baru. Namun tidak berarti kerjanya tidak memiliki nilai praktis. Sebaliknya, hal ini bisa membantu mengubah tingkah laku kita dan memperedalam apresiasi kita terhadap pikiran anak. Guru yang mengakui pencapaian linguiistik anak akan menyadari betapa bodohnya untuk terus menyoroti kelemahan anak berbahasa. Apa pun kekurangan bahasa mereka, ini masih terlalu kecil jika dibandingkan penguasaan mereka terhadap sistem gramatikanya yang kompleks. Guru SD yang seperti ini, setiap kali melihat anak baru akan berpikir. "Anak ini sudah mengembangkan kemampuan menakjubkan menguasai struktur linguistik. Pikiran seperti itu layak mendapat penghormatan terbesarku." Kita hanya bisa terkagum-kagum dengan efek tingkah laku ini.

Selain Chomsky masih banyak psikolog yang tidak bisa menerima fakta bahwa anak belajar bahasa dengan caranya sendiri. Mereka masih percaya bahwa di tangan kitalah tugas mengajar anak-anak gramatika dengan benar. Sebagai contoh, Bandura (1977:175) menyebutkan kalau kita mestinya mengoreksi bahasa anak yang berlebih-lebihan (seperti We digged the hole"). Chomsky malah melihat hal sebaliknya. Apa yang dilakukan anak adalah menyelidiki aturan-aturan yang melandasi kalimat, sebuah pencarian yang akhirnya membawah dia ada penguasaan gramatika yang rumit. Karena itu keliru jadinya jika kita turut campur tangan di dalam proses ini. Dengan mengoreksi kesalahan anak, kita hanya akan membuat mereka binging dan merusak kepercayaan diri mereka. Kekeliruan mereka akan diperbaiki sendiri pada waktunya. Daripada mengoreksi anak-anak lebih baik kita mengagumi kemajuan mereka. Kekaguman dan kesenagan kita secara diam-diam sangat membantu sebanyak koreksi yang kita berikan. Namun begitu banyak psikolog dan pendidik yang masih terus saja mengeksplorasi cara untuk memfasilitasi dan mengakselerasi ujran anak bahkan kepada mereka yang masih prasekolah (Wells, 1985; Whitehurst dkk, 1988). Yang termasuk di dalam kelompok ini adalah menggunkan pengulangan yang dikoreksi di mana banyak orang tua melakukan seperti 
ini. Sebagai contoh, kita mencatat bagaimana salah satu subjek Brown Adam, mengatakan, "There go one", dan ibunya merespons, "Yes, there goes one” (Brown dan Bellugi, 1964:140). Banyak anak meniru cara orang tua berbicara, dan sebaliknya, banyak orang tua secara alamiah berbicara kepada anak mereka dengan cara ini. Dan kedua pihak menikmati percakapan tersebut, walaupun tidak jelas apakah pengulangan yang dikoreksi ini bisa membantu pencapaian bahasa dalam kondisi apa pun (Dale, 1973, h.116-120;Wells, 1985; Cole, 1989, h.303).

\section{Daftar Pustaka}

Brown, A First Language. The Early Stages. Cambridge. MA: Harvard University Press. 1973.

--------, and Bellugi, U. Three Processes in the Child's Acquisition of Syntax. Harvard Educational Review 34. 1964.

---------, and Hanlon, C. Derivational Complexity and Order of Acquisition in Child Speech. Dalam Brown. R., Psycholinguistics: Selected Papers. New York: Free Press. 1970.

Bandura, A. Social Learning Theory. Englewood Cliffs, NJ: Prentice Hall. 1977.

Cairns, H.S., and Cairns, C.E., Psycholingiustics: A Cognitive View of Language. New York: Holt, Rinerhart \& Winston. 1976.

Chomsky, N. Interview. Dalam Cohen, D., Psychologists on Psychology. New York: Taplinger. 1977.

Ervin, S. M. Imitation and Structural Change in Children's Language. Cambridge. MA: MIT Press. 1964.

Gardner, Developmental Psychology: An Intruduction (Edisi II) . Boston, Litle, Brown. 1982.

Gleitmen, L. R. And Gleitmen, H. Language DalamH. Gleitmen, Psychology (edisi II). New York: W. W. Norton. 1986.

Hyms, N.M. Language Acquisition and the Theory of Parameters. Dordrecht, Holland D. Reider Publishing Co. 1986. 
Klima, E.S., and Bellugi, U. Syntactic Regularities in the Speech of Children. Dalam J. Lyons and R.J. Wales (Eds), Psycholinguistics Papers. Edinburgh: University Press. 1966.

Lovaas. O. The Autistic Child. New York: Halstead Press. 1977

Montessori, M. The Absorbent Mind (C.A Claremont, Terj.) New York: Holt. Rinehart \& Winston. 1967

Sachs, J.S. Development of Speech. Dalam E. C. Carterette and M.P. Friedman (Eds). Handbook of Perception (Vol. VII) New York: Academic Press. 1976.

Slobin. Psycholinguistic (edisi II). Glenview, IL: Scott, Foresman. 1979.

Sroufe and Cooper, R. G. Child Development: Its Nature and Course. New York: Knopf. 1988.

Turner, E. W., and Rommetveit, R. Experimental Manipulation of the production of active and passive Voice in children. Language and Speech 10. 1967. 